\title{
Treatment strategy for metastatic gastric cancer in Japan
}

\author{
Kojiro Eto', Satoshi Ida1', Masayuki Watanabe', Hideo Baba² \\ 1Department of Gastroenterological Surgery, Cancer Institute Hospital, Koto-ku, Tokyo 135-8550, Japan. \\ ${ }^{2}$ Department of Gastroenterological Surgery, Graduate School of Medical Sciences, Kumamoto University, Chuo-ku, Kumamoto \\ 860-0811, Japan.
}

Correspondence to: Dr. Masayuki Watanabe, Department of Gastroenterological Surgery, Cancer Institute Hospital, 3-8-31, Ariake, Koto-ku, Tokyo 135-8550, Japan. E-mail: masayuki.watanabe@jfcr.or.jp

How to cite this article: Eto K, Ida S, Watanabe M, Baba H. Treatment strategy for metastatic gastric cancer in Japan. J Cancer Metastasis Treat 2018;4:23. http://dx.doi.org/10.20517/2394-4722.2017.73

Received: 20 Dec 2017 First Decision: 13 Mar 2018 Revised: 4 Apr 2018 Accepted: 23 Apr 2018 Published: 16 May 2018

Science Editor: Lucio Miele Copy Editor: Jun-Yao Li Production Editor: Cai-Hong Wang

\begin{abstract}
Despite recent progress in diagnostic imaging, gastric cancer (GC) is occasionally found at an advanced stage with distant metastasis. As metastatic GC is difficult to cure, the treatment strategy should be considered individually based on the physical and socioeconomic status of patients as well as on the GC symptoms. The first choice of treatment for metastatic GC is chemotherapy, and several chemotherapeutic regimens for metastatic or recurrent GC have been developed through randomized controlled trials. Ongoing clinical trials will provide novel therapeutic options for patients with metastatic GC in the near future, while individualization of treatment based on detailed molecular information, socalled precision medicine, is eagerly anticipated. In this article, we review recent publications and guidelines focusing on recent progress in the treatment of metastatic GC in Japan.
\end{abstract}

Keywords: Gastric cancer, chemotherapy, molecularly targeted drug, para-aortic lymph node metastasis, liver metastasis

\section{INTRODUCTION}

Gastric cancer (GC) is the fourth most commonly diagnosed cancer and the second leading cause of cancer mortality worldwide ${ }^{[1,2]}$. A large-scale database analysis in the United States revealed that distant metastases were present in $34 \%$ of GC patients at the time of their GC diagnosis ${ }^{[3]}$. Although systematic screening programs have been developed in Japan to enable detection of early stage $G C^{[4]}$, GC is occasionally found at an advanced stage with distant metastasis. The first choice of treatment for patients with metastatic GC is chemotherapy ${ }^{[5]}$. Although recent advances in chemotherapy, including immune checkpoint inhibitors

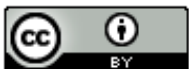

(C) The Author(s) 2018. Open Access This article is licensed under a Creative Commons Attribution 4.0 International License (https://creativecommons.org/licenses/by/4.0/), which permits unrestricted use, sharing, adaptation, distribution and reproduction in any medium or format, for any purpose, even commercially, as long as you give appropriate credit to the original author(s) and the source, provide a link to the Creative Commons license, and indicate if changes were made.

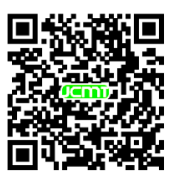


Table 1. Results of trials with chemotherapy for metastatic gastric cancer in Japan

\begin{tabular}{|c|c|c|c|c|}
\hline Authors, year & Regimen & Patients (n) & OS (months) & HR \\
\hline Koizumi et al. ${ }^{[8]}, 2008$ & $\begin{array}{l}\text { S-1 + cisplatine } \\
\text { S-1 }\end{array}$ & $\begin{array}{l}148 \\
150\end{array}$ & $\begin{array}{l}13.0 \\
11.0\end{array}$ & $\begin{array}{l}0.77(0.61-0.98) \\
1\end{array}$ \\
\hline Yamada et al. ${ }^{[33]}, 2015$ & $\begin{array}{l}\text { S-1 } \\
\text { Cisplatine + irinotecan } \\
\text { 5-FU continuous infusion }\end{array}$ & $\begin{array}{l}234 \\
236 \\
234\end{array}$ & $\begin{array}{l}11.4 \\
12.3 \\
10.8\end{array}$ & $\begin{array}{l}0.83(0.68-1.00) \\
0.82(0.68-0.99) \\
1\end{array}$ \\
\hline Koizumi et al. ${ }^{[34]}, 2014$ & $\begin{array}{l}\text { S-1 + docetaxel } \\
\text { S-1 }\end{array}$ & $\begin{array}{l}314 \\
321\end{array}$ & $\begin{array}{l}12.5 \\
10.8\end{array}$ & $\begin{array}{l}0.84(0.71-0.99) \\
1\end{array}$ \\
\hline Boku et al. ${ }^{[35]}, 2009$ & $\begin{array}{l}\text { S-1 } \\
\text { Cisplatine + irinotecan } \\
\text { 5-FU continuous infusion }\end{array}$ & $\begin{array}{l}234 \\
236 \\
234\end{array}$ & $\begin{array}{l}11.4 \\
12.3 \\
10.8\end{array}$ & $\begin{array}{l}0.83(0.68-1.00) \\
0.82(0.68-0.99) \\
1\end{array}$ \\
\hline Narahara et al. ${ }^{[36]}, 2011$ & $\begin{array}{l}\text { S-1 + irinotecan } \\
\text { S-1 }\end{array}$ & $\begin{array}{l}155 \\
160\end{array}$ & $\begin{array}{l}12.8 \\
10.5\end{array}$ & $\begin{array}{l}0.93 \\
1\end{array}$ \\
\hline Hironaka et al. ${ }^{[44]}, 2013$ & $\begin{array}{l}\text { Weekly paclitaxel } \\
\text { Weekly irinotecan }\end{array}$ & $\begin{array}{l}108 \\
111\end{array}$ & $\begin{array}{l}9.5 \\
8.4\end{array}$ & $\begin{array}{l}1.13(0.86-1.49) \\
1\end{array}$ \\
\hline Shitara et al. ${ }^{[45]}, 2017$ & $\begin{array}{l}\text { Tri-weekly nab-paclitaxel } \\
\text { Weekly nab-paclitaxel } \\
\text { Weekly paclitaxel }\end{array}$ & $\begin{array}{l}247 \\
246 \\
248\end{array}$ & $\begin{array}{l}10.3 \\
11.1 \\
1.06\end{array}$ & $\begin{array}{l}1.06(0.87-1.31) \\
0.97(0.76-1.23) \\
1\end{array}$ \\
\hline
\end{tabular}

OS: overall survival; HR: hazard ratio; 5-FU: 5-fluorouracil

and drugs targeting specific molecular pathways, have achieved an increase in the response rate, it is difficult to cure metastatic GC with chemotherapy alone. The current goals of treatment, therefore, are to relieve GC-related symptoms and to prolong survival. The median survival time achieved in clinical trials for metastatic or recurrent GC remains between 6 and 13 months $s^{[6-8]}$, although it has been proven that chemotherapy prolongs survival when compared with the best supportive care $(\mathrm{BSC})^{[9,10]}$. Recently, it has been reported that curative resection may be performed for patients with liver metastasis, para-aortic lymph node metastasis, or positive peritoneal cytology, especially when chemotherapy has been effective ${ }^{[1-19]}$. In this review, we summarize the publications and guidelines that have focused on recent progress in the treatment of metastatic GC in Japan.

\section{TREATMENT STRATEGY FOR METASTATIC GC}

The main treatment for metastatic GC is chemotherapy. Table 1 shows the representative trials for metastatic or recurrent GC in Japan. The first chemotherapeutic agent of choice against metastatic GC was 5-fluorouracil (5-FU), which was used either alone or in combination with various agents. In Japan, 5-FU as a key drug for GC was replaced by S-1 (tegafur-gimestat-otastat potassium), based on favorable results in trials involving Japanese patient ${ }^{[8,20]}$. Thereafter, trials focused on identifying the best combination regimen using S-1. Recently, many drugs designed to target the molecular pathways involved in the development or progression of cancer have been studied for metastatic $\mathrm{GC}^{[21-31]}$ [Table 2]. In patients with GC overexpressing human epidermal growth factor receptor 2 (HER2), the addition of trastuzumab, an antibody targeting HER2, to the first-line cytotoxic drug regimens significantly prolonged the survival of patients ${ }^{[21]}$. Therefore, the presence or absence of HER2 overexpression is the first branch point when selecting the treatment regimen. The recommended treatment algorithm for patients of metastatic GC in the 5th edition of the Japanese Gastric Cancer Treatment Guideline is shown in Figure 1. Recommendation A indicates that the regimen is strongly recommended based on the certain evidence while recommendation B suggests that the regimen is weakly recommended because of insufficient evidence. Figure 2 demonstrates the alternative algorithm for patients who are unfit for the standard treatment due to comorbidities or social situations.

\section{HER2-negative advanced GC}

In Japan, the first choice of chemotherapy for metastatic GC is S-1 and cisplatin (SP), according to the results of a phase III trial (SPIRITS trial $\left.{ }^{[8]}\right)$. This trial showed that patients treated with SP had significantly better overall survival (OS) than those treated with S-1 alone, with a median OS of 13 vs. 11 months $(P=0.04)$. Progression-free survival (PFS) was also significantly longer in patients treated with SP than in those treated 
Table 2. Results of completed phase III trials with molecular targeted therapy in advanced gastric cancer

\begin{tabular}{|c|c|c|c|c|c|}
\hline Target & Trial & Regimen & Patients $(n)$ & OS (months) & HR \\
\hline HER2 & ToGA ${ }^{[21]}$ & $\begin{array}{l}\text { Cisplatine, capecitabine or } \\
5-\mathrm{FU} \pm \text { trastuzumab }\end{array}$ & 584 & $\begin{array}{l}13.8 v s .11 .1 \\
\text { (1st line) }\end{array}$ & $0.74(0.60-0.91)$ \\
\hline HER2 & LOGiC $^{[48]}$ & $\begin{array}{l}\text { Capecitabine, oxaliplatin } \pm \\
\text { trastuzumab }\end{array}$ & 545 & $\begin{array}{l}12.2 \text { vs. } 10.5 \\
\text { (1st line) }\end{array}$ & $0.74(0.73-1.12)$ \\
\hline HER2 & TyTAN $^{[49]}$ & Paclitaxel \pm lapatinib & 261 & $\begin{array}{l}11.0 \text { vs. } 8.9 \\
\text { (1st line) }\end{array}$ & $0.84(0.64-1.11)$ \\
\hline EGFR & EXPAND $^{[26]}$ & $\begin{array}{l}\text { Cisplatine, capecitabine } \pm \\
\text { cetuximb }\end{array}$ & 679 & $\begin{array}{l}9.4 \text { vs. } 10.7 \\
\text { (1st line) }\end{array}$ & $1.09(0.92-1.29)$ \\
\hline EGFR & $\operatorname{REAL3}^{[27]}$ & $\begin{array}{l}\text { Oxaliplatin, capecitabine, } \\
\text { epirubicin } \pm \text { panitumumab }\end{array}$ & 553 & $\begin{array}{l}8.8 \text { vs. } 11.3 \\
\text { (1st line) }\end{array}$ & $1.37(1.07-1.76)$ \\
\hline VEGFR-2 & REGARD $^{[31]}$ & $\mathrm{BSC} \pm$ ramucirumab & 355 & $\begin{array}{l}5.2 \text { vs. } 3.8 \\
\text { (2nd line) }\end{array}$ & $0.77(0.60-0.99)$ \\
\hline VEGFR-2 & RAINBOW ${ }^{[30]}$ & Paclitaxel \pm ramucirumab & 665 & $\begin{array}{l}9.6 v s .7 .4 \\
\text { (2nd line) }\end{array}$ & $0.80(0.68-0.96)$ \\
\hline VEGFR-A & AVAGAST ${ }^{[24]}$ & $\begin{array}{l}\text { Cisplatine, capecitabine or } \\
5-\mathrm{FU} \pm \text { bevacizumab }\end{array}$ & 774 & $\begin{array}{l}12.1 v s .10 .1 \\
\text { (1st line) }\end{array}$ & $0.87(0.73-1.03)$ \\
\hline mTOR & GRANITE- $^{[25]}$ & $\mathrm{BSC} \pm$ everolimus & 633 & $\begin{array}{l}5.4 \text { vs. } 4.3 \\
\text { (2nd or 3rd line) }\end{array}$ & $0.90(0.75-1.08)$ \\
\hline
\end{tabular}

OS: overall survival; HR: hazard ratio; 5-FU: 5-fluorouracil; BSC: best supportive care

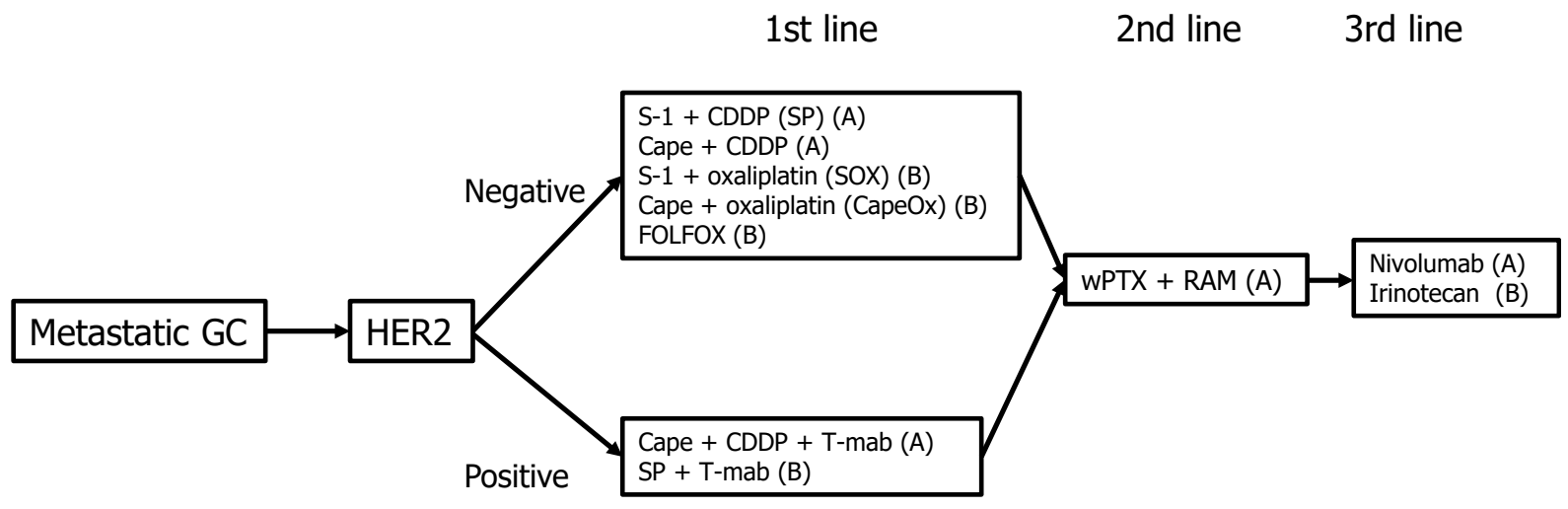

Figure 1. The treatment algorithm for advanced gastric cancer in Japan

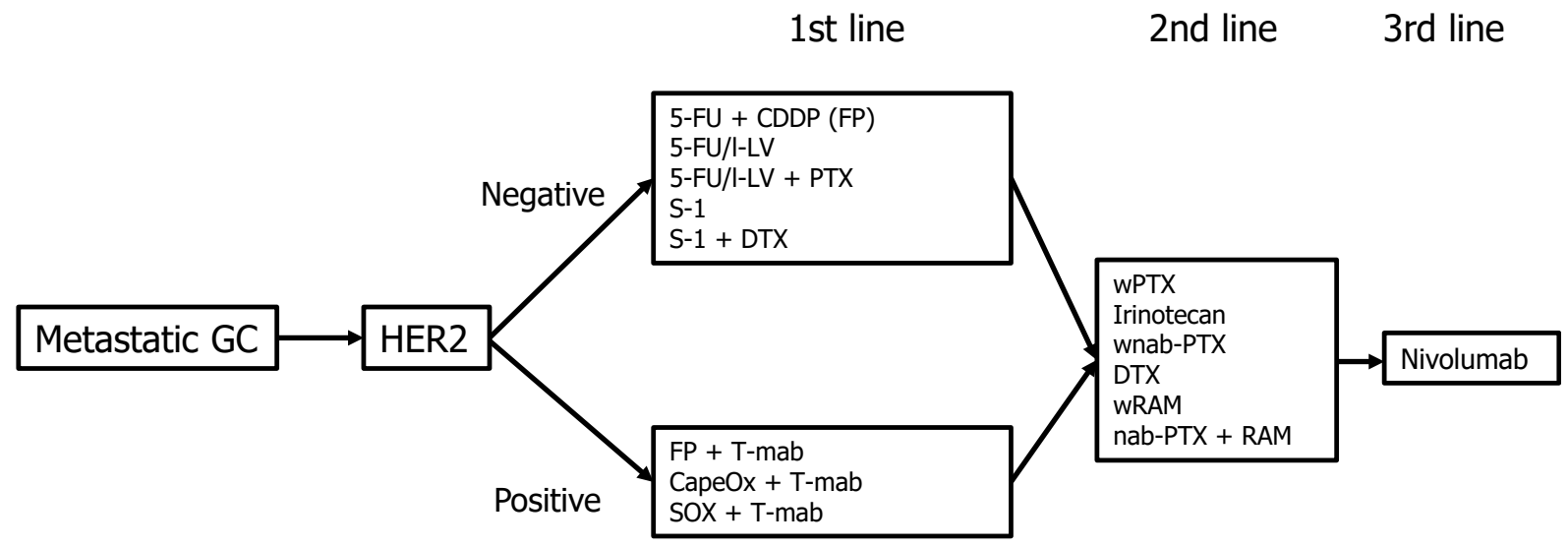

Figure 2. The treatment algorithm for patients who are unfit for the standard treatment in Japan

with S-1 alone, with a median PFS of 6 vs. 4 months $(P<0.0001)$. The response rate of SP in this study was $54 \%$; among 87 patients in the SP group, $46(52.9 \%)$ achieved partial response and $1(1.1 \%)$ had a complete response. 
Capecitabine and cisplatin (Cape/CDDP) combination is one of the standard first-line regimens for patients with metastatic or recurrent GC worldwide. Cape/CDDP has been employed as a control regimen in global phase III trials, including the ToGA ${ }^{[2]}$ and AVAGAST trials ${ }^{[24]}$. The subset analyses of the Japanese participants in these trials have shown safety and efficacy of this regimen; therefore, Cape/CDDP is a firstline treatment choice for Japanese patients.

The REAL-2 trial ${ }^{[32]}$ evaluated whether fluorouracil could be replaced with capecitabine, and cisplatin replaced with oxaliplatin, in the epirubicin, 5-FU and cisplatin (ECF) regimen. This trial demonstrated that capecitabine and oxaliplatin are as effective as 5-FU and cisplatin, respectively, in patients with previously untreated esophagogastric cancer. Cisplatin causes renal toxicity and intravenous hydration is required to decrease the toxicity. Oxaliplatin does not require hydration and can be administered in an outpatient clinic. In Japan, the combination of S-1 plus oxaliplatin (SOX) appears to be as effective as SP for metastatic GC, with a favorable safety profile ${ }^{[33]}$.

The superiority of a combination of S-1 and docetaxel (DTX) to S-1 monotherapy as first-line treatment was evaluated in the START trial ${ }^{[34]}$ which included Japanese and Korean patients with metastatic or recurrent GC. Although the initial survival analysis failed to demonstrate superiority after clarifying the outcomes of censored cases, a reanalysis demonstrated the efficacy of this regimen [OS 12.5 vs. 10.8 months, hazard ratio (HR) 0.84, 95\% CI: 0.71-0.99, $P=0.032$ ]. Therefore, $S-1 / \mathrm{DTX}$ can be selected as an alternative to SP, Cape/CDDP, or SOX. Both irinotecan (CPT-11) plus cisplatin and S-1 plus CPT-11 combinations failed to demonstrate survival benefit over 5-FU alone or S-1 alone, and are not recommended as a first-line regimen ${ }^{[35,36]}$.

Regarding triplet regimens, the V325 trial ${ }^{[37]}$ demonstrated survival benefits of docetaxel, cisplatin, and 5-FU (DCF) over cisplatin and 5-FU (CF), although grade 3 or 4 toxicities were more frequent with DCF than CF. In Japan, a triplet regimen consisting of S-1, cisplatin and docetaxel is currently being evaluated in a phase III trial, JCOG1013, based on the favorable results of a phase II trial in Japan ${ }^{[38-40]}$.

Based on these findings, the Japanese guidelines recommend SP or Cape/CDDP as first-line treatment of HER2-negative metastatic GC, and SOX, CapeOX, FOLFOX, FP and S-1/DTX are recommended as alternatives.

\section{HER2-positive advanced GC}

The ToGA trial showed that trastuzumab combined with conventional chemotherapy provided a significant survival advantage compared with chemotherapy alone in patients with HER2 positive metastatic or recurrent $\mathrm{GC}^{[21]}$. A total of 584 patients who had HER2-positive advanced GC or gastroesophageal junction cancer were randomly assigned to chemotherapy (consisting of CF or Cape/CDDP) with or without trastuzumab. The addition of trastuzumab significantly improved OS from 11.1 to 13.8 months $(P=0.0046)$, as compared with chemotherapy alone. In addition, PFS increased from 5.5 to 6.7 months (HR 0.7, 95\% CI: 0.59-0.85, $P=0.0002$ ). In the subgroup analysis, the survival benefit was more evident in the group of patients who had immunohistochemistry (IHC) $3+$ or IHC 2+/fluorescent in-situ hybridization (FISH)-positive tumors than in the others. The addition of trastuzumab increased survival from 11.8 to 16.0 months (HR 0.65, 95\% CI: $0.51-0.83, P=0.036$ ) among this cohort. Therefore, trastuzumab is recommended for patients with IHC $3+$ or IHC 2+/FISH positive tumors. A phase II trial to explore the efficacy and toxicity of trastuzumab combined with triweekly SP enrolled a total of 56 patients ${ }^{[4]}$. The response rate and the disease control rate were $68 \%$ (95\% CI: 54\%-80\%) and 94\% (95\% CI: $84 \%-99 \%)$, respectively. The median OS and PFS were 16.0 and 7.8 months, respectively. Major grade 3 or 4 adverse events included neutropenia (36\%), anorexia (23\%), and anemia (15\%). Although the study was not a randomized controlled trial, SP plus trastuzumab is considered to be a first-line chemotherapy choice for HER2-positive metastatic GC in Japan. 
Accordingly, the recommended first-line treatment of HER2-positive metastatic GC in Japan is a combination of trastuzumab and Cape/CDDP or a combination of trastuzumab and SP.

\section{Second-line treatment}

Second-line chemotherapy is known to prolong the survival of metastatic GC patients, and is recommended for patients with acceptable performance status. Among cytotoxic agents, monotherapy with DTX, CPT-11 or paclitaxel (weekly administration, wPTX) are available options. Randomized trials conducted in Germany ${ }^{[42]}$ and Korea ${ }^{[43]}$ have indicated survival benefits of DTX or CPT-11 over BSC. The German study ${ }^{[42]}$ compared CPT-11 as a second-line chemotherapy with BSC but was ended prematurely due to poor accrual. The median OS was 4.0 vs. 2.4 months in the CPT-11 and placebo arms, respectively $(P=0.012)$. The Korean study ${ }^{[43]}$ compared either CPT-11 or DTX as salvage chemotherapy (SLC) with BSC. The median OS of the SLC and the BSC arms were 5.1 and 3.8 months $(P=0.004)$, respectively. The WJOG4007 $7^{[44]}$ compared wPTX with CPT-11 in Japanese patients with advanced GC, after failure of primary combination chemotherapy using fluoropyrimidine plus cisplatin. The median OS of wPTX and CPT-11 groups was 9.5 and 8.4 months, respectively $(P=0.38)$. In addition, third-line chemotherapy was administered in $89.8 \%$ of the wPTX group and in $72.1 \%$ of the CPT-11 group. Based on these findings, both wPTX and CPT-11 are considered reasonable second-line treatment options for advanced GC.

More recently, two large international phase III trials (REGARD and RAINBOW) have revealed the survival benefits of ramucirumab, a fully human monoclonal antibody against the vascular endothelial growth factor receptor (VEGFR)-2 ${ }^{[30,31]}$ for previously treated advanced gastric or gastroesophageal junction (GEJ) adenocarcinoma. In the REGARD trial ${ }^{[31]}$, patients were randomly assigned (2:1) to receive BSC plus either intravenous ramucirumab $8 \mathrm{mg} / \mathrm{kg}$ or placebo once every 2 weeks. The median OS was 5.2 months in the ramucirumab group and 3.8 months in the placebo group (HR: 0.77, 95\% CI: 0.60-0.99; $P=0.047$ ), while the median PFS was 2.1 and 1.3 months, respectively. Ramucirumab appeared to be well tolerated, although rates of hypertension were higher in the ramucirumab group than in the placebo group. The RAINBOW trial ${ }^{[30]}$ compared ramucirumab plus PTX $v$ s. placebo plus PTX in patients with previously treated advanced GC. Patients were randomly assigned in a 1:1 ratio to receive either intravenous ramucirumab $8 \mathrm{mg} / \mathrm{kg}$ or placebo on days 1 and 15, plus intravenous PTX $80 \mathrm{mg} / \mathrm{m}^{2}$ on days 1, 8, and 15 of a 28-day cycle. OS was significantly longer in ramucirumab plus PTX group than in the placebo plus PTX group (the median OS of 9.6 and 7.4 months, $P=0.017$ ). The toxicity of ramucirumab plus PTX was tolerable.

Nab-paclitaxel (nab-PTX) is a nanoparticle-albumin-bound paclitaxel and it does not contain the solvent cremophor EL and ethanol. Therefore, nab-paclitaxel can reduce the risk of a hypersensitivity reaction and can be administered to patients who are intolerant of alcohol. The ABSOLUTE trial ${ }^{[45]}$ is a phase III study to evaluate the efficacy and safety of nab-PTX $v s$. wPTX in Japanese patients with advanced GC refractory to first-line chemotherapy. The median OS was 10.3 months in the nab-PTX every 3 weeks group, 11.1 months in the weekly nab-PTX group and 10.9 months in the wPTX group. Weekly nab-PTX was non-inferior to wPTX in terms of OS.

In summary, the recommended second-line treatment for metastatic GC in Japan is ramucirumab plus wPTX, and the alternative choice is monotherapy of either DTX, CPT-11, nab-PTX or ramucirumab.

\section{Immune checkpoint inhibitors in GC treatment}

The ATTRACTION-2 (ONO-4358-12) trial evaluated the efficacy and safety of nivolumab, a fully human IgG4 monoclonal antibody inhibitor of programmed death-1, in patients with advanced GC or GEJ cancer who had been treated with two or more chemotherapy regimens ${ }^{[46]}$. The median OS was 5.26 months in the nivolumab group and 4.14 months in the placebo group (HR 0.63, 95\% CI: $0.51-0.78 ; P<0.0001$ ). The 
safety profile of nivolumab in patients with advanced GC or GEJ cancer was manageable and similar to that reported in patients with other advanced solid tumors. Based on these results, the Japanese Ministry of Health, Labor and Welfare approved nivolumab for the treatment of unresectable advanced or recurrent GC which has progressed after chemotherapy. Currently, trials are ongoing to evaluate the efficacy of immune checkpoint inhibitors in earlier lines of GC treatment.

\section{Ongoing trials in Japan}

The RAINFALL trial is ongoing to evaluate the effectiveness of ramucirumab in combination with Cape/ CDDP compared to Cape/CDDP alone as first-line treatment of metastatic GC or GEJ adenocarcinoma (NCT02314117). The SOLAR trial, a phase III trial comparing TAS-118 (S-1 plus leucovorin) and oxaliplatin vs. SP as first-line treatment, is recruiting patients with advanced GC in Japan and Korea (NCT02322593).

\section{Precision medicine for GC}

Treatment of cancer is likely to shift and be tailored towards personalized therapy based on detailed molecular information, known as precision medicine. The Cancer Genome Atlas Research Network reported the results of molecular classification of GC through integrative genomic analysis, which suggested that GC could be divided into four subtypes ${ }^{[47]}$ : (1) Epstein-Barr virus-related tumors; (2) microsatellite instability represented as elevated mutation rates and MLH1 silencing; (3) genomically stable tumors that are strongly related with diffuse histology, RHOA mutations, and CLDN18-ARHGAP fusion; and (4) chromosomal instability that mainly comprises intestinal histology, TP53 mutation, and focal amplification of the receptor tyrosine kinase. Another study reported that GC can be classified into four subtypes ${ }^{[48]}$ : (1) microsatellite unstable; (2) microsatellite stable (MSS) with TP53 mutation; (3) MSS without TP53 mutation; and (4) MSS with epithelial-to-mesenchymal transition (EMT). This study found that the MSS/EMT subtype was related to poor prognosis. Further analysis is needed to establish genome-based precision medicine.

\section{CONCLUSION}

The main goal of treatment for metastatic GC patients is to prolong patient survival while preserving quality of life. In addition to the combination of conventional cytotoxic drugs, several newly developed agents, including targeted molecules and immune checkpoint inhibitors, have shown favorable results in the treatment of metastatic GC. Efforts should be focused on achieving precision medicine based on the molecular information of GC.

\section{DECLARATIONS}

\section{Authors' contributions}

Concept, design, literature search, and manuscript preparation: Eto K

Manuscript editing: Ida S

Design, manuscript editing, and manuscript review: Watanabe $\mathrm{M}$

Manuscript review: Baba $\mathrm{H}$

\section{Financial support and sponsorship}

None.

\section{Conflicts of interest}

Authors declare that they have no conflicts of interest.

\section{Patient consent}

Not applicable. 


\section{Ethics approval}

Not applicable.

\section{Copyright}

(c) The Author(s) 2018 .

\section{REFERENCES}

1. Ferlay J, Shin HR, Bray F, Forman D, Mathers C, Parkin DM. Estimates of worldwide burden of cancer in 2008: GLOBOCAN 2008. Int J Cancer 2010;127:2893-917.

2. Kamangar F, Dores GM, Anderson WF. Patterns of cancer incidence, mortality, and prevalence across five continents: defining priorities to reduce cancer disparities in different geographic regions of the world. J Clin Oncol 2006;24:2137-50.

3. Zhang G, Zhao X, Li J, Yuan Y, Wen M, Hao X, Li P, Zhang A. Racial disparities in stage-specific gastric cancer: analysis of results from the Surveillance Epidemiology and End Results (SEER) program database. J Investig Med 2017;65:991-8.

4. Yamamoto M, Rashid OM, Wong J. Surgical management of gastric cancer: the East vs. West perspective. J Gastrointest Oncol 2015;6:79-88

5. Japanese Gastric Cancer Association. Japanese gastric cancer treatment guidelines 2014 (ver. 4). Gastric Cancer 2017;20:1-19.

6. Shirasaka T, Nakano K, Takechi T, Satake H, Uchida J, Fujioka A, Saito H, Okabe H, Oyama K, Takeda S, Unemi N, Fukushima M. Antitumor activity of $1 \mathrm{M}$ tegafur-0.4 M 5-chloro-2,4-dihydroxypyridine-1 M potassium oxonate (S-1) against human colon carcinoma orthotopically implanted into nude rats. Cancer Res 1996;56:2602-6.

7. Ohtsu A, Shimada Y, Shirao K, Boku N, Hyodo I, Saito H, Yamamichi N, Miyata Y, Ikeda N, Yamamoto S, Fukuda H, Yoshida S. Randomized phase III trial of fluorouracil alone versus fluorouracil plus cisplatin versus uracil and tegafur plus mitomycin in patients with unresectable, advanced gastric cancer: The Japan Clinical Oncology Group Study (JCOG9205). J Clin Oncol 2003;21:54-9.

8. Koizumi W, Narahara H, Hara T, Takagane A, Akiya T, Takagi M, Miyashita K, Nishizaki T, Kobayashi O, Takiyama W, Toh Y, Nagaie T, Takagi S, Yamamura Y, Yanaoka K, Orita H, Takeuchi M. S-1 plus cisplatin versus S-1 alone for first-line treatment of advanced gastric cancer (SPIRITS trial): a phase III trial. Lancet Oncol 2008;9:215-21.

9. Murad AM, Santiago FF, Petroianu A, Rocha PR, Rodrigues MA, Rausch M. Modified therapy with 5-fluorouracil, doxorubicin, and methotrexate in advanced gastric cancer. Cancer 1993;72:37-41.

10. Pyrhonen S, Kuitunen T, Nyandoto P, Kouri M. Randomised comparison of fluorouracil, epidoxorubicin and methotrexate (FEMTX) plus supportive care with supportive care alone in patients with non-resectable gastric cancer. Br J Cancer 1995;71:587-91.

11. Yoshikawa T, Sasako M, Yamamoto S, Sano T, Imamura H, Fujitani K, Oshita H, Ito S, Kawashima Y, Fukushima N. Phase II study of neoadjuvant chemotherapy and extended surgery for locally advanced gastric cancer. Br J Surg 2009;96:1015-22.

12. Tsuburaya A, Mizusawa J, Tanaka Y, Fukushima N, Nashimoto A, Sasako M. Neoadjuvant chemotherapy with S-1 and cisplatin followed by D2 gastrectomy with para-aortic lymph node dissection for gastric cancer with extensive lymph node metastasis. Br J Surg 2014;101:653-60.

13. Sakamoto Y, Ohyama S, Yamamoto J, Yamada K, Seki M, Ohta K, Kokudo N, Yamaguchi T, Muto T, Makuuchi M. Surgical resection of liver metastases of gastric cancer: an analysis of a 17-year experience with 22 patients. Surgery 2003;133:507-11.

14. Sakamoto Y, Sano T, Shimada K, Esaki M, Saka M, Fukagawa T, Katai H, Kosuge T, Sasako M. Favorable indications for hepatectomy in patients with liver metastasis from gastric cancer. J Surg Oncol 2007;95:534-9.

15. Takemura N, Saiura A, Koga R, Yoshioka R, Yamamoto J, Kokudo N. Repeat hepatectomy for recurrent liver metastasis from gastric carcinoma. World J Surg 2013;37:2664-70.

16. Kinoshita T, Saiura A, Esaki M, Sakamoto H, Yamanaka T. Multicentre analysis of long-term outcome after surgical resection for gastric cancer liver metastases. Br J Surg 2015;102:102-7.

17. Jamel S, Markar SR, Malietzis G, Acharya A, Athanasiou T, Hanna GB. Prognostic significance of peritoneal lavage cytology in staging gastric cancer: systematic review and meta-analysis. Gastric Cancer 2018;21:10-8.

18. Cabalag CS, Chan ST, Kaneko Y, Duong CP. A systematic review and meta-analysis of gastric cancer treatment in patients with positive peritoneal cytology. Gastric Cancer 2015;18:11-22.

19. Kuramoto M, Shimada S, Ikeshima S, Matsuo A, Yagi Y, Matsuda M, Yonemura Y, Baba H. Extensive intraoperative peritoneal lavage as a standard prophylactic strategy for peritoneal recurrence in patients with gastric carcinoma. Ann Surg 2009;250:242-6.

20. Tsuburaya A, Sakamoto J, Morita S, Kodera Y, Kobayashi M, Miyashita Y, Macdonald JS. A randomized phase III trial of post-operative adjuvant oral fluoropyrimidine versus sequential paclitaxel/oral fluoropyrimidine; and UFT versus S1 for T3/T4 gastric carcinoma: The Stomach Cancer Adjuvant Multi-Institutional Trial Group (Samit) Trial. Jpn J Clin Oncol 2005;35:672-5.

21. Bang YJ, Van Cutsem E, Feyereislova A, Chung HC, Shen L, Sawaki A, Lordick F, Ohtsu A, Omuro Y, Satoh T, Aprile G, Kulikov E, Hill J, Lehle M, Ruschoff J, Kang YK. Trastuzumab in combination with chemotherapy versus chemotherapy alone for treatment of HER2-positive advanced gastric or gastro-oesophageal junction cancer (ToGA): a phase 3, open-label, randomised controlled trial. Lancet 2010;376:687-97.

22. Fuchs CS, Marshall J, Mitchell E, Wierzbicki R, Ganju V, Jeffery M, Schulz J, Richards D, Soufi-Mahjoubi R, Wang B, Barrueco J. Randomized, controlled trial of irinotecan plus infusional, bolus, or oral fluoropyrimidines in first-line treatment of metastatic colorectal cancer: results from the BICC-C Study. J Clin Oncol 2007;25:4779-86. 
23. Fuchs CS, Tomasek J, Yong CJ, Dumitru F, Passalacqua R, Goswami C, Safran H, dos Santos LV, Aprile G, Ferry DR, Melichar B, Tehfe M, Topuzov E, Zalcberg JR, Chau I, Campbell W, Sivanandan C, Pikiel J, Koshiji M, Hsu Y, Liepa AM, Gao L, Schwartz JD, Tabernero J. Ramucirumab monotherapy for previously treated advanced gastric or gastro-oesophageal junction adenocarcinoma (REGARD): an international, randomised, multicentre, placebo-controlled, phase 3 trial. Lancet 2014;383:31-9.

24. Ohtsu A, Shah MA, Van Cutsem E, Rha SY, Sawaki A, Park SR, Lim HY, Yamada Y, Wu J, Langer B, Starnawski M, Kang YK. Bevacizumab in combination with chemotherapy as first-line therapy in advanced gastric cancer: a randomized, double-blind, placebocontrolled phase III study. J Clin Oncol 2011;29:3968-76.

25. Ohtsu A, Ajani JA, Bai YX, Bang YJ, Chung HC, Pan HM, Sahmoud T, Shen L, Yeh KH, Chin K, Muro K, Kim YH, Ferry D, Tebbutt NC, Al-Batran SE, Smith H, Costantini C, Rizvi S, Lebwohl D, Van Cutsem E. Everolimus for previously treated advanced gastric cancer: results of the randomized, double-blind, phase III GRANITE-1 study. J Clin Oncol 2013;31:3935-43.

26. Lordick F, Kang YK, Chung HC, Salman P, Oh SC, Bodoky G, Kurteva G, Volovat C, Moiseyenko VM, Gorbunova V, Park JO, Sawaki A, Celik I, Gotte H, Melezinkova H, Moehler M. Capecitabine and cisplatin with or without cetuximab for patients with previously untreated advanced gastric cancer (EXPAND): a randomised, open-label phase 3 trial. Lancet Oncol 2013;14:490-9.

27. Waddell T, Chau I, Cunningham D, Gonzalez D, Okines AF, Okines C, Wotherspoon A, Saffery C, Middleton G, Wadsley J, Ferry D, Mansoor W, Crosby T, Coxon F, Smith D, Waters J, Iveson T, Falk S, Slater S, Peckitt C, Barbachano Y. Epirubicin, oxaliplatin, and capecitabine with or without panitumumab for patients with previously untreated advanced oesophagogastric cancer (REAL3): a randomised, open-label phase 3 trial. Lancet Oncol 2013;14:481-9.

28. Shah MA, Ramanathan RK, Ilson DH, Levnor A, D'Adamo D, O’Reilly E, Tse A, Trocola R, Schwartz L, Capanu M, Schwartz GK, Kelsen DP. Multicenter phase II study of irinotecan, cisplatin, and bevacizumab in patients with metastatic gastric or gastroesophageal junction adenocarcinoma. J Clin Oncol 2006;24:5201-6.

29. Shah MA, Jhawer M, Ilson DH, Lefkowitz RA, Robinson E, Capanu M, Kelsen DP. Phase II study of modified docetaxel, cisplatin, and fluorouracil with bevacizumab in patients with metastatic gastroesophageal adenocarcinoma. J Clin Oncol 2011;29:868-74.

30. Wilke H, Muro K, Van Cutsem E, Oh SC, Bodoky G, Shimada Y, Hironaka S, Sugimoto N, Lipatov O, Kim TY, Cunningham D, Rougier P, Komatsu Y, Ajani J, Emig M, Carlesi R, Ferry D, Chandrawansa K, Schwartz JD, Ohtsu A. Ramucirumab plus paclitaxel versus placebo plus paclitaxel in patients with previously treated advanced gastric or gastro-oesophageal junction adenocarcinoma (RAINBOW): a double-blind, randomised phase 3 trial. Lancet Oncol 2014;15:1224-35.

31. Fuchs CS, Tomasek J, Yong CJ, Dumitru F, Passalacqua R, Goswami C, Safran H, Dos Santos LV, Aprile G, Ferry DR, Melichar B, Tehfe M, Topuzov E, Zalcberg JR, Chau I, Campbell W, Sivanandan C, Pikiel J, Koshiji M, Hsu Y, Liepa AM, Gao L, Schwartz JD, Tabernero J. Ramucirumab monotherapy for previously treated advanced gastric or gastro-oesophageal junction adenocarcinoma (REGARD): an international, randomised, multicentre, placebo-controlled, phase 3 trial. Lancet 2014;383:31-9.

32. Cunningham D, Starling N, Rao S, Iveson T, Nicolson M, Coxon F, Middleton G, Daniel F, Oates J, Norman AR. Capecitabine and oxaliplatin for advanced esophagogastric cancer. N Engl J Med 2008;358:36-46.

33. Yamada Y, Higuchi K, Nishikawa K, Gotoh M, Fuse N, Sugimoto N, Nishina T, Amagai K, Chin K, Niwa Y, Tsuji A, Imamura H, Tsuda M, Yasui H, Fujii H, Yamaguchi K, Hironaka S, Shimada K, Miwa H, Hamada C, Hyodo I. Phase III study comparing oxaliplatin plus S-1 with cisplatin plus S-1 in chemotherapy-naive patients with advanced gastric cancer. Ann Oncol 2015;26:141-8.

34. Koizumi W, Kim YH, Fujii M, Kim HK, Imamura H, Lee KH, Hara T, Chung HC, Satoh T, Cho JY, Hosaka H, Tsuji A, Takagane A, Inokuchi M, Tanabe K, Okuno T, Ogura M, Yoshida K, Takeuchi M, Nakajima T. Addition of docetaxel to S-1 without platinum prolongs survival of patients with advanced gastric cancer: a randomized study (START). J Cancer Res Clin Oncol 2014;140:319-28.

35. Boku N, Yamamoto S, Fukuda H, Shirao K, Doi T, Sawaki A, Koizumi W, Saito H, Yamaguchi K, Takiuchi H, Nasu J, Ohtsu A. Fluorouracil versus combination of irinotecan plus cisplatin versus S-1 in metastatic gastric cancer: a randomised phase 3 study. Lancet Oncol 2009;10:1063-9.

36. Narahara H, Iishi H, Imamura H, Tsuburaya A, Chin K, Imamoto H, Esaki T, Furukawa H, Hamada C, Sakata Y. Randomized phase III study comparing the efficacy and safety of irinotecan plus S-1 with S-1 alone as first-line treatment for advanced gastric cancer (study GC0301/TOP-002). Gastric Cancer 2011;14:72-80.

37. Ajani JA, Moiseyenko VM, Tjulandin S, Majlis A, Constenla M, Boni C, Rodrigues A, Fodor M, Chao Y, Voznyi E, Awad L, Van Cutsem E. Quality of life with docetaxel plus cisplatin and fluorouracil compared with cisplatin and fluorouracil from a phase III trial for advanced gastric or gastroesophageal adenocarcinoma: The V-325 Study Group. J Clin Oncol 2007;25:3210-6.

38. Koizumi W, Nakayama N, Tanabe S, Sasaki T, Higuchi K, Nishimura K, Takagi S, Azuma M, Ae T, Ishido K, Nakatani K, Naruke A, Katada C. A multicenter phase II study of combined chemotherapy with docetaxel, cisplatin, and S-1 in patients with unresectable or recurrent gastric cancer (KDOG 0601). Cancer Chemother Pharmacol 2012;69:407-13.

39. Sato Y, Takayama T, Sagawa T, Takahashi Y, Ohnuma H, Okubo S, Shintani N, Tanaka S, Kida M, Ohta H, Miyanishi K, Sato T, Takimoto R, Kobune M, Yamaguchi K, Hirata K, Niitsu Y, Kato J. Phase II study of S-1, docetaxel and cisplatin combination chemotherapy in patients with unresectable metastatic gastric cancer. Cancer Chemother Pharmacol 2010;66:721-8.

40. Fushida S, Fujimura T, Oyama K, Yagi Y, Kinoshita J, Ohta T. Feasibility and efficacy of preoperative chemotherapy with docetaxel, cisplatin and S-1 in gastric cancer patients with para-aortic lymph node metastases. Anticancer Drugs 2009;20:752-6.

41. Kurokawa Y, Sugimoto N, Miwa H, Tsuda M, Nishina S, Okuda H, Imamura H, Gamoh M, Sakai D, Shimokawa T, Komatsu Y, Doki Y, Tsujinaka T, Furukawa H. Phase II study of trastuzumab in combination with S-1 plus cisplatin in HER2-positive gastric cancer (HERBIS-1). Br J Cancer 2014;110:1163-8.

42. Thuss-Patience PC, Kretzschmar A, Bichev D, Deist T, Hinke A, Breithaupt K, Dogan Y, Gebauer B, Schumacher G, Reichardt P. Survival advantage for irinotecan versus best supportive care as second-line chemotherapy in gastric cancer--a randomised phase III 
study of the Arbeitsgemeinschaft Internistische Onkologie (AIO). Eur J Cancer 2011;47:2306-14.

43. Kang JH, Lee SI, Lim DH, Park KW, Oh SY, Kwon HC, Hwang IG, Lee SC, Nam E, Shin DB, Lee J, Park JO, Park YS, Lim HY, Kang WK, Park SH. Salvage chemotherapy for pretreated gastric cancer: a randomized phase III trial comparing chemotherapy plus best supportive care with best supportive care alone. J Clin Oncol 2012;30:1513-8.

44. Hironaka S, Ueda S, Yasui H, Nishina T, Tsuda M, Tsumura T, Sugimoto N, Shimodaira H, Tokunaga S, Moriwaki T, Esaki T, Nagase M, Fujitani K, Yamaguchi K, Ura T, Hamamoto Y, Morita S, Okamoto I, Boku N, Hyodo I. Randomized, open-label, phase III study comparing irinotecan with paclitaxel in patients with advanced gastric cancer without severe peritoneal metastasis after failure of prior combination chemotherapy using fluoropyrimidine plus platinum: WJOG 4007 trial. J Clin Oncol 2013;31:4438-44.

45. Shitara K, Takashima A, Fujitani K, Koeda K, Hara H, Nakayama N, Hironaka S, Nishikawa K, Makari Y, Amagai K, Ueda S, Yoshida K, Shimodaira H, Nishina T, Tsuda M, Kurokawa Y, Tamura T, Sasaki Y, Morita S, Koizumi W. Nab-paclitaxel versus solvent-based paclitaxel in patients with previously treated advanced gastric cancer (ABSOLUTE): an open-label, randomised, non-inferiority, phase 3 trial. Lancet Gastroenterol Hepatol 2017;2:277-87.

46. Kang YK, Boku N, Satoh T, Ryu MH, Chao Y, Kato K, Chung HC, Chen JS, Muro K, Kang WK, Yeh KH, Yoshikawa T, Oh SC, Bai LY, Tamura T, Lee KW, Hamamoto Y, Kim JG, Chin K, Oh DY, Minashi K, Cho JY, Tsuda M, Chen LT. Nivolumab in patients with advanced gastric or gastro-oesophageal junction cancer refractory to, or intolerant of, at least two previous chemotherapy regimens (ONO-4538-12, ATTRACTION-2): a randomised, double-blind, placebo-controlled, phase 3 trial. Lancet 2017;390:2461-71.

47. Cancer Genome Atlas Research Network. Comprehensive molecular characterization of gastric adenocarcinoma. Nature 2014;513:202-9.

48. Cristescu R, Lee J, Nebozhyn M, Kim KM, Ting JC, Wong SS, Liu J, Yue YG, Wang J, Yu K, Ye XS, Do IG, Liu S, Gong L, Fu J, Jin JG, Choi MG, Sohn TS, Lee JH, Bae JM, Kim ST, Park SH, Sohn I, Jung SH, Tan P, Chen R, Hardwick J, Kang WK, Ayers M, Hongyue D, Reinhard C, Loboda A, Kim S, Aggarwal A. Molecular analysis of gastric cancer identifies subtypes associated with distinct clinical outcomes. Nat Med 2015;21:449-56.

49. Satoh T, Xu RH, Chung HC, Sun GP, Doi T, Xu JM, Tsuji A, Omuro Y, Li J, Wang JW, Miwa H, Qin SK, Chung IJ, Yeh KH, Feng JF, Mukaiyama A, Kobayashi M, Ohtsu A, Bang YJ. Lapatinib plus paclitaxel versus paclitaxel alone in the second-line treatment of HER2amplified advanced gastric cancer in Asian populations: TyTAN--a randomized, phase III study. J Clin Oncol 2014;32:2039-49. 